\title{
ANALISIS PENGELOLAAN DANA DESA DALAM PEMBERDAYAAN EKONOMI MASYARAKAT MELALUI BADAN USAHA MILIK GAMPONG (BUMG) DI GAMPONG CAPA PALOH KECAMATAN PADANG TIJI KABUPATEN PIDIE
}

\author{
(Analysis of Village Fund Management in Community Economic Empowerment Through \\ Village Owned Enterprises in Capa Paloh, Padang Tiji, Pidie))
}

\author{
Nurul Fitri ${ }^{1}$, Anwar Deli ${ }^{1}$, Fajri $^{1 *}$ \\ ${ }^{1}$ Program Studi Agribinis, Fakultas Pertanian, Universitas Syiah Kuala
}

\begin{abstract}
Abstrak. Dalam penyelenggaraan pemerintahan atau otonominya, desa membutuhkan sumber keuangan desa agar bisa melaksanakan sendiri pembangunannya. Salah satu pendapatan yang masuk dalam keuangan desa adalah dana desa. Anggaran dana desa diprioritaskan untuk membiayai pembangunan dan pemberdayaan masyarakat desa. Aceh berada di urutan ketiga yang menjadi provinsi yang paling banyak menerima dana desa Tahun 2017 sebesar Rp 4.892 triliun. Kabupaten Pidie merupakan kabupaten kedua di Provinsi Aceh yang paling besar menerima dana desa. Dana desa yang diterima tersebut dibagikan kepada 730 desa, termasuk Desa Capa Paloh. Adapun dana desa yang diterima oleh Desa Capa Paloh pada tahun 2017 sebesar Rp 737.714.734,-. Dari anggaran dana desa yang dikhususkan untuk pemberdayaan ekonomi masyarakat, Gampong Capa Paloh memanfaatkan dana desa tersebut untuk pemberdayaan ekonomi masyarakat melalui penyertaan modal untuk Badan Usaha Milik Desa yang biasa disingkat dengan BUMDes atau Badan Usaha Milik Gampong (BUMG) sebesar Rp 80.000.000,- Tujuan penelitian ini adalah untuk mendeskripsikan dan mengetahui tinfkat efektivitas dan efesiensi pengelolaan dana gampong pada BUMG Capa Paloh. Metode analisis yang digunakan adalah deskriptif kualitatif. Hasil penelitian ini menunjukkan pengelolaan dana gampong pada BUMG Capa Paloh secara umum telah dilakukan sesuai dengan peraturan yang telah ditetapkan. Diperoleh nilai efektivitas yaitu 119,2\% yang berarti sangat efektif, dan nilai efesiensi diperoleh sebesar 304,21\% yang berarti tidak efesien.
\end{abstract}

Kata Kunci : BUMG, pengelolaan, efektivitas, efesiensi.

Abstract. In the administration of government or autonomy, the village needs village financial resources so that it can carry out its own development. One of the income included in village finance is village funds. Village fund budgets are prioritized to finance development and empowerment of rural communities. Aceh is in the third place which is the province that receives the most village funds in 2017 amounting to Rp 4,892 trillion. Pidie Regency is the second district in Aceh Province which receives the most village funds. The village funds received were distributed to 730 villages, including Capa Paloh Village. The village funds received by Capa Paloh Village in 2017 amounted to Rp. 737,714,734. From the village funds budget devoted to community economic empowerment, Gapa Village Capa Paloh utilizes the village funds to empower the community's economy through equity participation Badan Usaha Milik Desa commonly abbreviated as BUMDes or Badan Usaha Milik Gampong (BUMG) Rp. 80,000,000. - The purpose of this research is to describe and find out the level of effectiveness and efficiency of village fund management at BUMG Capa Paloh. The analytical method used is descriptive qualitative. The results of this study indicate that the management of village funds in BUMG Capa Paloh in general has been carried out in accordance with established regulations. The effectiveness value is $119.2 \%$ which means it is very effective, and the efficiency value is $304.21 \%$ which means it is not efficient.

.Keywords :BUMG, management, effectiveness, efficiency. 


\section{PENDAHULUAN}

Berbagai upaya terus dilakukan oleh Pemerintah Indonesia dalam mendorong pembangunan nasional. Pembangunan daerah pedesaan menjadi yang sangat penting diperhatikan dalam pembangunan nasional. Pemerintah mengeluarkan Undang-Undang Nomor 6 Tahun 2014 tentang Desa yang menjadi bentuk awal kemandirian desa dalam hal penyelenggaraan sebuah pemerintah. Dalam penyelenggaraan, desa membutuhkan sumber keuangan desa dan salah satu sumber keuangan desa adalah dana desa. Dana desa merupakan dana yang berasal dari Anggaran Pendapatan dan Belanja Negara (APBN) dan ditujukan kepada desa untuk mendanai penyelenggaraan pemerintahannya, pelaksanaan pembangunannya, pembinaan masyarakat, dan juga pemberdayaan masyarakat desa. Dalam penggunaannya, dana desa yang kini ditransfer kepada seluruh desa setiap tahunnya harus dapat dipertanggungjawabkan dan pengelolaannya juga dilakukan secara mandiri. Pemerintah desa mengelola keuangan tersebut melalui APBDesa.

Peraturan Menteri Desa, Pembangunan Daerah Tertinggal, dan Transmigrasi Republik Indonesia Nomor 22 Tahun 2016 mengatakan bahwa anggaran dana desa diprioritaskan untuk membiayai pembangunan dan pemberdayaan masyarakat desa. Pemberdayaan masyarakat pada prinsipnya yaitu upaya yang dilakukan dalam penguatan individu atau masyarakat agar mampu memperoleh dan mengelola faktor-faktor produksi serta penguatan individu atau masyarakat agar mampu menentukan pilihannya sendiri. Pemberdayaan masyarakat adalah salah satu upaya yang dilaksanakan untuk mendorong dan mendukung masyarakat agar terlepas dari belenggu kemiskinan. Upaya pemberdayaan ekonomi masyarakat harus menjadi komitmen utama dari pemerintah yang ada di desa dikarenakan dengan adanya upaya tersebut diharapkan bisa mengurangi tingkat kemiskinan di desa.

Aceh berada di urutan ketiga yang menjadi provinsi yang paling banyak menerima dana desa Tahun 2017 sebesar Rp 4.892 triliun. Kabupaten Pidie merupakan kabupaten kedua di Provinsi Aceh yang paling besar menerima dana desa. Dana desa yang diterima tersebut dibagikan kepada 730 desa, termasuk Desa Capa Paloh. Adapun dana desa yang diterima oleh Desa Capa Paloh pada tahun 2017 sebesar Rp 737.714.734,-. Dana desa yang diterima tersebut digunakan untuk penyelenggaraan pemerintahan, untuk membiayai pembangunan dan juga pemberdayaan masyarakat. Adapun salah satu pemberdayaan masyarakat yang dilaksanakan adalah di bidang pemberdayaan ekonomi. Dari anggaran dana desa yang dikhususkan untuk pemberdayaan ekonomi masyarakat, Gampong Capa Paloh memanfaatkan dana desa tersebut untuk pemberdayaan ekonomi masyarakat melalui penyertaan modal untuk Badan Usaha Milik Desa yang biasa disingkat dengan BUMDes atau Badan Usaha Milik Gampong (BUMG) sebesar Rp 80.000.000,-. Dengan adanya dana desa yang telah dialokasikan untuk penyertaan modal BUMG dalam menjalankan usaha tentu saja memerlukan pengelolaan. Dengan demikian perlu dilakukan penelitian yang ditujukan untuk menganalisis pengelolaan serta mengetahui efektivitas dan efesiensi dari pengelolaannya. Penelitian ini bertujuan untuk mendeskripsikan pengelolaan dan mengetahui tingkat efektivitas dan efesiensi pengelolaan dana gampong pada Badan Usaha Milik Gampong (BUMG) Capa Paloh.

Analisis Pengelolaan Dana Desa dalam Pemberdayaan Ekonomi Masyarakat Melalui Badan Usaha Milik 595 Gampong di Gampong Capa Paloh Kecamatan Padang Tiji Kabupaten Pidie (Nurul Fitri, Anwar Deli, Fajri) 


\section{Tempat dan Waktu Penelitian}

\section{METODE PENELITIAN}

Penelitian ini dilakukan di Gampong Capa Paloh Kecamatan Padang Tiji Kabupaten Pidie. Waktu penelitian dilaksanakan pada bulan April tahun 2018.

\section{Objek dan Ruang Lingkup Penelitian}

Objek dari penelitian ini adalah pemerintah desa, pengurus BUMG, dan pihak-pihak yang dirasakan memiliki banyak pengetahuan tentang informasi yang berkaitan dengan masalah pengelolaan dana desa dalam pemberdayaan ekonomi masyarakat melalui BUMG di Gampong Capa Paloh Kecamatan Padang Tiji Kabupaten Pidie. Ruang lingkup ini dibatasi pada pengelolaan Dana Desa dalam pemberdayaan ekonomi masyarakat serta efesiensi dan efektivitas pengelolaan Dana Desa dalam pemberdayaan ekonomi masyarakat di gampong tersebut.

\section{Model Penelitian}

Model penelitian yang digunakan dalam penelitian ini adalah studi kasus dengan pendekatan yang digunakan adalah pendekatan deskriptif. Dalam penelitian ini, sumber data yang dipilih menggunakan teknik purposive sampling yang telah ditentukan kriterianya, yaitu sejauh mana mereka memahami masalah yang akan diteliti. Adapun yang dijadikan sumber data dalam penelitian ini adalah pemerintah gampong pengurus BUMG, dan pihak penerima modal.

\section{Metode Pengumpulan Data}

Data yang dikumpulkan merupakan data primer dan sekunder. Data primer diperoleh dengan observasi terhadap dana gampong pada BUMG dengan mengumpulkan berbagai laporan kinerja dari BUMG, wawancara langsung dan memberikan pertanyaan-pertanyaan terhadap informan yang telah ditentukan. Data sekunder adalah data yang didapat dari internet, artikel, jurnal, dan hasil penelitian lainnya yang dapat dijadikan acuan dalam penelitian ini.

\section{Metode Analisis}

Pada pengelolaan Dana Desa dalam pemberdayaan ekonomi masyarakat ini model yang digunakan yaitu menggunakan deskriptif kualitatif dengan langkah-langkah seperti yang dikemukan oleh Bungin (2007), yaitu sebagai berikut:

a. Pengumpulan data (Data Collection)

Pengumpulan data pada penelitian ini adalah dengan menggunakan metode wawancara langsung kepada informan yang bersangkutan dan studi dokumentasi terhadap pengelolaan dana gampong pada BUMG Capa Paloh.

b. Reduksi data (Data Reduction)

Reduksi data merupakan proses pemilihan, pemusatan, penyederhanaan dan transformasi data yang muncul dari catatan-catatan yang diperoleh di lapangan.

c. Display data

Display data merupakan tahap pendeskripsian sekumpulan informasi yang memberikan kemungkinan adanya penarikan kesimpulan.

d. Verifikasi dan penegasan kesimpulan (Conclusion Drawing and Verification)

Penarikan kesimpulan berupa kegiatan interpretasi, yaitu menemukan makna data yang telah disajikan. Data yang sebelumnya sudah didapatkan di lokasi penelitian terkait akan dibandingkan dengan peraturan atau Undang-Undang yang telah dibuat berkenaan dengan pengelolaan dana Desa melalui BUMG.

Analisis Pengelolaan Dana Desa dalam Pemberdayaan Ekonomi Masyarakat Melalui Badan Usaha Milik 596 Gampong di Gampong Capa Paloh Kecamatan Padang Tiji Kabupaten Pidie (Nurul Fitri, Anwar Deli, Fajri)

Jurnal Ilmiah Mahasiswa Pertanian Unsyiah, Vol. 3, No. 4, November 2018: 594-607 
Untuk menganalisis tingkat efesiensi dalam pengelolaan keuangan dengan melihat perbandingan antara realisasi anggaran belanja dengan realisasi anggaran pendapatan sebagai berikut:

$$
\text { Efesiensi }=\frac{\text { Pengeluaran }}{\text { Pendapatan }} \times 100 \%
$$

Tabel 1. Kategori dan persentase hasil analisis efesiensi anggaran pemberdayaan ekonomi masyarakat

\begin{tabular}{ccc}
\hline No. & Kategori & Persentase \\
\hline 1 & Tidak Efesien & $>100 \%$ \\
\hline 2 & Kurang Efesien & $90 \%-100 \%$ \\
\hline 3 & Cukup Efesien & $80 \%-89,9 \%$ \\
\hline 4 & Efesien & $60 \%-79,9 \%$ \\
\hline 5 & Sangat Efesien & $<60 \%$ \\
\hline
\end{tabular}

Untuk menganalisis tingkat efektivitas dalam pengelolaan keuangan dengan melihat perbandingan sebagai berikut:

$$
\text { Efektivitas }=\frac{\text { Realisasi Anggaran }}{\text { Anggaran yang Tersedia }} \times 100 \%
$$

Tabel 2. Kategori dan persentase hasil analisis efesiensi anggaran pemberdayaan ekonomi masyarakat

\begin{tabular}{ccc}
\hline No. & Kategori & Persentase \\
\hline 1 & Sangat efektif & $>100 \%$ \\
\hline 2 & Efektif & $90 \%-100 \%$ \\
\hline 3 & Cukup Efektif & $80 \%-89,9 \%$ \\
\hline 4 & Kurang Efektif & $60 \%-79,9 \%$ \\
\hline 5 & Tidak Efektif & $<60 \%$ \\
\hline
\end{tabular}

Sumber : Keputusan Mendagri No. 690.900.327 tahun 1996

\section{HASIL PENELITIAN DAN PEMBAHASAN \\ Profil Badan Usaha Milik Gampong (BUMG) Capa Paloh}

Badan Usaha Milik Gampong (BUMG) ini bernama Badan Usaha Milik Gampong Capa Paloh. BUMG ini didirikan pada tahun 2012 dengan musyawarah. Adapun tujuan dari pendirian BUMG ini adalah sebagai upaya untuk meningkatkan pendapatan gampong dan juga masyarakatnya. BUMG ini didirikan atas beberapa dasar yaitu, adanya inisiatif pemerintah gampong dan masyarakat berdasarkan musyawarah, adanya potensi usaha ekonomi masyarakat, tersedianya sumber daya gampong yang belum dimanfaatkan secara optimal, dan adanya sumber daya manusia yang mampu mengelola usaha tersebut. Adapun Organisasi pengelola BUMG disini terdiri dari penasihat, pelaksana operasional, dan pengawas yang memiliki tugas untuk menjalankan dan mengembangkan BUMG ini.

Sejak didirikannya BUMG ini pada tahun 2012 hingga tahun 2016 ada penyertaan modal untuk BUMG yang berasal dari dana PNPM. Akan tetapi, usaha yang dijalankan oleh BUMG tersebut hanya berupa simpan pinjam dan tidak memperoleh keuntungan dari kegiatan tersebut. Lalu pada bulan Januari tahun 2017 dana tersebut dialihkan kepada pengurus BUMG yang baru sebesar Rp 41.900.000,- dan mulailah dijalankan dengan

Analisis Pengelolaan Dana Desa dalam Pemberdayaan Ekonomi Masyarakat Melalui Badan Usaha Milik 597 Gampong di Gampong Capa Paloh Kecamatan Padang Tiji Kabupaten Pidie (Nurul Fitri, Anwar Deli, Fajri) Jurnal Ilmiah Mahasiswa Pertanian Unsyiah, Vol. 3, No. 4, November 2018: 594-607 
beberapa usaha yaitu penggemukan lembu, penggemukan kambing, dan modal turun sawah. Usaha tersebut dimulai pada awal tahun 2017 dan diterapkan sistem bagi hasil dari usaha tersebut sehingga pihak BUMG dan pihak penerima modal sama-sama memperoleh keuntungan dari bagi hasil tersebut.

Lalu pada bulan Oktober penyertaan modal untuk BUMG bertambah sebesar Rp 80.000.000,- yang mana penyertaan modal tersebut diperoleh dari Dana Desa tahun anggaran 2017 yang dialokasikan untuk penambahan modal BUMG. Dengan penambahan modal dari dana desa tersebut maka modal yang dimiliki BUMG yaitu sebesar Rp 121.900.000,-. Dengan bertambahnya dana tersebut maka BUMG berkesempatan untuk mengembangkan usaha-usaha yang dijalankannya.

Di dalam Peraturan Bupati Pidie Nomor 14 Tahun 2012 tentang pedoman tata cara pembentukan dan pengelolaan Badan Usaha Milik Gampong (BUMG) di Kabupaten Pidie dikatakan bahwa tata cara pembentukan dan pengelolaan BUMG ditetapkan dengan Qanun Gampong, dan kesepakatan dari musyawarah dituangkan dalam AD/ART yang sekurangkurangnya berisi: organisasi dan tata kerja, penetapan personil, sistem pertanggungjawaban dan pelaporan, bagi hasil dan kepailitan. Namun, pada BUMG Capa Paloh ini belum adanya Qanun Gampong yang berisikan tata cara pembentukan dan pengelolaan BUMG, dan belum adanya juga AD/ART seperti yang sudah dijelaskan di dalam Peraturan Bupati Pidie Nomor 14 Tahun 2012. Tata cara pembentukan dan pengelolaan serta hasil kesepakatan musyawarah dari BUMG Capa Paloh ini belum ditulis secara resmi di dalam Qanun Gampong dan dituangkan dalam AD/ART. Akan tetapi, meskipun belum ditulis secara resmi, pengelolaan BUMG Capa Paloh ini pengelolaannya tetap dijalankan berdasarkan hasil kesepatakan dari musyawarah.

\section{Pengelolaan Badan Usaha Milik Gampong (BUMG) Capa Paloh Perencanaan}

Berkenaan dengan perencanaan BUMG, perencanaannya dilakukan atas dasar inisiatif pemerintah gampong dan masyarakat melalui musyawarah desa. Musyawarah tersebut dilakukan di Mesjid yang dihadiri oleh pemerintah gampong, pengurus BUMG dan masyarakat. Dalam musyawarah tersebut bukan hanya membahas mengenai masalah BUMG, tetapi ada berbagai hal yang dibahas, yaitu mengenai kegiatan-kegiatan yang akan didanai oleh Dana Desa serta besarnya anggaran yang dialokasikan untuk mendanai kegiatan-kegiatan tersebut.

Khusus untuk BUMG, perencanaan yang dibahas yaitu mengenai jumlah dana yang tersedia, usaha-usaha yang dijalankan, bagi hasil yang diterapkan, serta apa saja kewajiban yang dilakukan oleh penerima modal dan sanksi yang akan diberikan apabila penerima modal melakukan sesuatu yang dapat merugikan BUMG. Di dalam perencanaan tersebut diperoleh bahwa usaha-usaha yang dijalankan oleh BUMG yaitu usaha penggemukan kambing dan penggemukan lembu. Keputusan tersebut diperoleh dengan mempertimbangkan bahwa masyarakat Capa Paloh yang dominan memiliki pekerjaan sebagai tani cenderung ingin memiliki usaha sambilan yaitu pemeliharaan ternak dan usaha tersebut tidak bisa dijalankan karena tidak cukupnya modal yang dimiliki oleh masyarakat tersebut.

Penyertaan modal BUMG adalah sebesar Rp 80.000.000,-. Besarnya penyertaan modal untuk BUMG tersebut 10,84\% dari total dana desa tahun 2017 yang diterima yaitu sebesar Rp 737.714.734. Angka tersebut masih terlalu sedikit karena mengingat BUMG ini

Analisis Pengelolaan Dana Desa dalam Pemberdayaan Ekonomi Masyarakat Melalui Badan Usaha Milik 598 Gampong di Gampong Capa Paloh Kecamatan Padang Tiji Kabupaten Pidie (Nurul Fitri, Anwar Deli, Fajri)

Jurnal Ilmiah Mahasiswa Pertanian Unsyiah, Vol. 3, No. 4, November 2018: 594-607 
penting dalam membantu pertumbuhan ekonomi di Gampong Capa Paloh seperti yang diungkapkan oleh Keuchik Capa Paloh ketika dilakukan wawancara. Namun hal itu disebabkan karena pada kegiatan yang didanai oleh dana desa tahun 2017 lebih diprioritaskan untuk membiayai pelaksanaan program dan kegiatan di bidang pembangunan desa. Hal itu sesuai dengan Peraturan Menteri Desa, Pembangunan Daerah Tertinggal, dan Transmigrasi Republik Indonesia Nomor 22 Tahun 2016 yang menjelaskan bahwa prioritas penggunaan dana desa salah satunya didasarkan pada prinsip kebutuhan prioritas dengan mendahulukan kepentingan desa yang lebih mendesak.

\section{Pelaksanaan Operasional}

Pelaksana operasional pada BUMG terdiri dari Muhammad Jakfar sebagai ketua, Musafir sebagai Sekretaris, Saiful Tambi sebagai bendahara. Pelaksana operasional tersebut diangkat oleh Keuchik sendiri dan sewaktu-waktu bisa berhenti atau diberhentikan apabila meninggal dunia, mengundurkan diri, pindah tempat tinggal di luar gampong, tidak dapat melaksanakan tugas dengan baik sehingga menghambat pertumbuhan dan perkembangan BUMG, tidak lagi memenuhi syarat-syarat sebagaimana ditetapkan, melanggar norma susila dan agama, atau karena tersangkut tindak pidana berdasarkan putusan hakim.

Pelaksana operasional disini terpisah dari organisasi pemerintah gampong dan pelaksana operasional BUMG ini tidak boleh merangkap jabatan di pemerintahan gampong. Pelaksana operasional juga tidak boleh anggota pengelola perseroan, perusahaan swasta, atau jabatan yang lain yang berhubungan dengan pengelola perusahaan, pejabat struktural dan/atau fungsional dalam instansi/lembaga pemerintah pusat, pemerintah daerah dan/atau pemerintah gampong. Adapun masa bakti pelaksana operasional kepengurusan BUMG ini ditetapkan untuk masa 3 tahun dan dapat dipilih kembali pada masa bakti berikutnya. Adapun kriteria yang diperhatikan dalam menentukan pelaksana operasional disini adalah beragama islam, sehat jasmani dan rohani, bertempat tinggal dan menetap di gampong, berpendidikan minimal SMA atau sederajat, berkepribadian jujur, adil, dan bisa bekerjasama.

Tugas dari pelaksana operasional adalah melaksanakan apa yang telah direncanakan sebelumnya pada musyawarah desa diantaranya yaitu mengawasi dan mengontrol jalannya usaha yang dikelola oleh masyarakat yang merupakan usaha dari BUMG, membuat laporan keuangan dari usaha BUMG tersebut, menyampaikan laporan keseluruhan kepada penasihat dan pengawas, memberikan sanksi kepada masyarakat yang mengelola usaha jika terjadinya suatu hal yang tidak diinginkan, mengadakan musyawarah untuk membahas bagaimana perkembangan jalannya usaha BUMG tersebut, serta melakukan upaya untuk mengembangkan dan membina BUMG agar tumbuh dan berkembang menjadi lembaga yang dapat melayani kebutuhan ekonomi warga masyarakat.

Adapun untuk tunjangan penghasilan pelaksana operasional, tidak terdapatnya tunjangan penghasilan pokok. Tunjangan penghasilan yang diberikan kepada pelaksana operasional adalah berupa bagi hasil yang diterima oleh BUMG. Alokasi untuk tunjangan penghasilan untuk pelaksana operasional adalah sebesar 40\% (empat puluh persen) dari bagi hasil yang diterima BUMG. Kemudian alokasi sebesar 40\% (empat puluh persen) tersebut dibagi untuk ketiga pelaksana operasional yang terdiri dari ketua, sekretrais, dan bendahara. Dalam menentukan besarnya tunjangan penghasilan untuk pelaksana operasional tersebut ditentukan berdasarkan kesepakatan dalam musyawarah.

Analisis Pengelolaan Dana Desa dalam Pemberdayaan Ekonomi Masyarakat Melalui Badan Usaha Milik 599 Gampong di Gampong Capa Paloh Kecamatan Padang Tiji Kabupaten Pidie (Nurul Fitri, Anwar Deli, Fajri)

Jurnal Ilmiah Mahasiswa Pertanian Unsyiah, Vol. 3, No. 4, November 2018: 594-607 


\section{Penasihat dan Pengawasan}

Penasihat BUMG ini dijabat secara ex officio oleh kepala desa, sedangkan pengawas BUMG ini terdiri dari dua yaitu pengawas internal dan eksternal. Pengawas internal dijabat oleh Tuha Peut dari gampong tersebut sedangkan pengawas eksternal dijabat oleh pendamping desa dari kabupaten. Adapun tugas penasihat dan pengawas internal adalah mengawasi tugas dan kinerja dari pelaksana operasional, mengawasi perkembangan usaha yang dijalankan, dan juga mengawasi pergerakan keuangan dalam BUMG tersebut, memberikan saran dan pendapat mengenai masalah yang dihadapi BUMG, serta meberikan nasihat kepada pelaksana operasional dalam menjalankan kegiatan pengelolaan BUMG. Sedangkan untuk pengawas eksternal, belum adanya pengawasan secara aktif dari pendamping desa untuk meninjau langsung jalannya usaha yang dikelola oleh BUMG. Selama BUMG ini berjalan belum adanya keterlibatan langsung dari pendamping desa dalam mengawasi dan melakukan evaluasi kepada BUMG Capa Paloh.

\section{Modal BUMG}

Pada dasarnya penyertaan modal BUMG terdiri atas penyertaan modal desa dan penyertaan modal masyarakat. Akan tetapi, penyertaan modal pada BUMG ini hanya berasal dari penyertaan modal desa saja. Penyertaan modal pertama yaitu berasal dari dana PNPM yang dialokasikan untuk BUMG sejak tahun 2012 sampai tahun 2014. Pada tahun 2012 hingga tahun 2016 hanya dilakukan simpan pinjam dan tidak diperoleh keuntungan dari kegiatan tersebut. Hingga pada bulan Januari tahun 2017 dana tersebut dialihkan kepada pengurus BUMG yang baru yaitu sebesar Rp 41.900.000,-.

Kemudian penyertaan modal kedua untuk BUMG diperoleh dari dana desa tahun anggaran 2017 yang dialokasikan untuk penambahan modal BUMG adalah sebesar Rp 80.000.000,- dan dapat dilihat pada tabel 7 mengenai kegiatan yang didanai oleh dana desa tahun 2017. Dengan dialokasikannya dana desa tahun 2017 untuk penambahan modal BUMG tersebut, maka modal BUMG pun bertambah menjadi Rp 121.900.000,-. Dan untuk dana desa periode selanjutnya jumlah penyertaan modal BUMG ini direncanakan akan bertambah yang disebabkan karena mengingat betapa pentingnya BUMG ini dalam membantu pendapatan masyarakat dan juga pendapatan desa.

Jumlah dana yang dialokasikan untuk penyertaan modal BUMG tersebut merupakan hasil musyawarah oleh pemerintah gampong dan masyarakat. Besarnya alokasi dana untuk BUMG tersebut berdasarkan pertimbangan terhadap hal-hal lain yang harus diprioritaskan terlebih dahulu seperti pembangunan infrastruktur yang masih harus dilakukan pembangunannya.

\section{Jenis Usaha yang Dijalankan}

Usaha yang dijalankan oleh BUMG sudah berlangsung selama 2 periode. Periode pertama yaitu dengan modal yang berasal dari PNPM tahun 2012-2014 sebesar Rp 41.900.000,- dan periode kedua yaitu dengan modal yang berasal dari dana desa tahun 2017 yaitu sebesar Rp 80.000.000,-. Jadi, selama 2 periode ini jumlah modal yang diberikan oleh gampong untuk penyertaan modal BUMG adalah sebesar Rp 121.900.000,-.

Analisis Pengelolaan Dana Desa dalam Pemberdayaan Ekonomi Masyarakat Melalui Badan Usaha Milik 600 Gampong di Gampong Capa Paloh Kecamatan Padang Tiji Kabupaten Pidie (Nurul Fitri, Anwar Deli, Fajri)

Jurnal Ilmiah Mahasiswa Pertanian Unsyiah, Vol. 3, No. 4, November 2018: 594-607 
Tabel 3. Usaha-usaha yang dijalankan oleh BUMG Capa Paloh

\begin{tabular}{|c|c|c|c|c|}
\hline No. & Nama & Jenis Usaha & Jumlah & Nilai (Rp) \\
\hline 1. & $\mathrm{ZK}$ & Penggemukan kambing & 4 (ekor) & 4.150.000,- \\
\hline 2. & SM & Penggemukan kambing & 3 (ekor) & $2.850 .000,-$ \\
\hline 3. & SF & Penggemukan lembu & 1 (ekor) & $8.250 .000,-$ \\
\hline 4. & $\mathrm{BL}$ & Penggemukan lembu & 1 (ekor) & $8.150 .000,-$ \\
\hline 5. & SN & Penggemukan lembu & 1 (ekor) & $8.500 .000,-$ \\
\hline 6. & ML & Penggemukan lembu & 1 (ekor) & 9.400.000,- \\
\hline 7. & $\mathrm{IZ}$ & Penggemukan lembu & 1 (ekor) & 9.600.000,- \\
\hline 8. & FS & Modal turun sawah & - & 13.000.000,- \\
\hline 9. & MJ & Penggemukan kambing & 5 (ekor) & 6.650.000,- \\
\hline 10. & IDR & Penggemukan kambing & 3 (ekor) & 3.500.000,- \\
\hline 11. & $\mathrm{DD}$ & Penggemukan kambing & 4 (ekor) & 4.900.000,- \\
\hline 12. & RF & Penggemukan kambing & 5 (ekor) & $5.500 .000,-$ \\
\hline 13. & FR & Penggemukan kambing & 2 (ekor) & $2.200 .000,-$ \\
\hline 14. & $\mathrm{MZ}$ & Penggemukan kambing & 5 (ekor) & $5.800 .000,-$ \\
\hline 15. & $\mathrm{~KB}$ & Penggemukan kambing & 3 (ekor) & $3.165 .000,-$ \\
\hline 16. & $\mathrm{BL}$ & Penggemukan lembu & 1 (ekor) & $9.700 .000,-$ \\
\hline 17. & KP & Penggemukan lembu & 1 (ekor) & $9.000 .000,-$ \\
\hline 18. & ML & Gadai sawah & $0,5(\mathrm{Ha})$ & $31.050 .000,-$ \\
\hline \multicolumn{4}{|c|}{ Jumlah } & 145.365.000,- \\
\hline
\end{tabular}

Sumber: Data primer diolah, 2018

Usaha yang dijalankan yaitu penggemukan kambing, penggemukan lembu, dan pinjam modal turun sawah, dan gadai sawah. Untuk usaha penggemukan kambing dijalankan oleh 9 orang dengan jumlah kambing yang berbeda. Adapun jumlah kambing tersebut berdasarkan atas permintaan pihak yang menjalankan usaha. Dan batas maksimal yang diberikan oleh BUMG adalah 5 ekor. Sedangkan untuk usaha penggemukan lembu dijalankan oleh 7 orang dengan jumlah lembu yang sama yaitu 1 ekor setiap orangnya. Jumlah tersebut sudah menjadi ketentuan BUMG bahwasanya untuk usaha penggemukan lembu hanya diberikan 1 ekor per orang. Kemudian untuk pinjam modal turun sawah, BUMG memberikan pinjaman modal yaitu sebesar Rp 13.000.000,-. Jumlah ini didasarkan atas permintaan dari pihak peminjam, dan disetujui oleh pihak BUMG karena adanya kecukupan dana yang tersedia. Dan untuk gadai sawah menggunakan modal dari BUMG yaitu sebesar Rp 31.050.000.

Dapat dilihat pada tabel 3. Tersebut bahwa BUMG menggunakan modal BUMG sebesar Rp 145.365.000,- padahal modal yang diberikan BUMG hanya sebesar Rp 121.900.000,-. Hal itu disebabkan karena modal BUMG memiliki penambahan dari keuntungan yang diperoleh dari bagi hasil yang telah dilaksanakan dan pengembalian modal dari petani dan peternak. Sehingga, BUMG menggunakan modal yang telah diterima kembali dan hasil keuntungan dari bagi hasil tersebut untuk dikelola kembali.

\section{Tata Cara dalam Menjalankan Usaha BUMG}

Adapun tata cara dalam menjalankan usaha BUMG ini, BUMG memberikan modal kepada pengusaha penggemukan kambing dan penggemukan lembu bukan berupa uang melainkan BUMG membeli bibit ternak dan kemudian menyerahkannya kepada peternak yang menjalankan usaha tersebut. Sedangkan untuk modal turun sawah dan gadai tanah,

Analisis Pengelolaan Dana Desa dalam Pemberdayaan Ekonomi Masyarakat Melalui Badan Usaha Milik 601 Gampong di Gampong Capa Paloh Kecamatan Padang Tiji Kabupaten Pidie (Nurul Fitri, Anwar Deli, Fajri) Jurnal Ilmiah Mahasiswa Pertanian Unsyiah, Vol. 3, No. 4, November 2018: 594-607 
modal yang diberikan adalah berupa uang.

Untuk usaha penggemukan kambing dan penggemukan lembu, bibit ternak yang telah diberikan tersebut dipelihara oleh si peternak. Jika si peternak tidak mempunyai kandang, maka si peternak bisa melakukan peminjaman kepada BUMG dan harus dikembalikan sesuai dengan jumlah uang yang dipinjam. Untuk biaya pemeliharaan dan perawatan ditanggung sendiri oleh si peternak dan tidak ada kaitannya lagi dengan BUMG. Dalam membantu perawatannya, BUMG hanya memberikan bantuan pemberian vaksin untuk ternak yang dilakukan oleh pengurus BUMG yang mana vaksin tersebut bertujuan agar ternak tidak rentan terserang penyakit.

Adapun kewajiban dari peternak adalah merawat dan menjaga keamanan ternak dari penyakit dan pencurian ternak. Pengurus BUMG berkewajiban mengontrol dan mengawasi pertumbuhan dan perkembangan dari ternak tersebut. Untuk penjualannya tidak ada batas waktu yang diberikan. Kapanpun si peternak ingin menjual ternak tersebut maka harus dilaporkan kepada pihak BUMG. Kemudian pihak BUMG akan bekerjasama dengan peternak tersebut dalam proses penjualannya.

\section{Sistem Bagi Hasil dan Sanksi}

Bagi hasil merupakan pembagian atas hasil usaha yang dibiayai oleh modal BUMG. Bagi hasil dalam BUMG ini yaitu antara pihak yang menjalankan usaha dan pihak BUMG. Adapun kesepakatan mengenai bagi hasil diperoleh melalui musyawarah antara pemerintah gampong, pengurus BUMG, dan masyarakat sendiri. Hasil dari kesepatan dari bagi hasil tersebut disajikan pada tabel di bawah ini.

Tabel 4. Bagi hasil yang diterapkan BUMG

\begin{tabular}{clll}
\hline No. & \multicolumn{1}{c}{ Jenis Usaha } & BUMG & Pengusaha \\
\hline 1. & Penggemukan kambing & $1 / 3$ bagian & $2 / 3$ bagian \\
\hline 2. & Penggemukan lembu & $1 / 3$ bagian & $2 / 3$ bagian \\
\hline 3. & Modal turun sawah & $1 / 3$ bagian & $2 / 3$ bagian \\
\hline 4. & Gadai Tanah & $1 / 5$ bagian & $4 / 5$ bagian \\
\hline
\end{tabular}

Sumber: Data primer diolah, 2018

Dapat dilihat pada tabel 4. yaitu bagi hasil untuk usaha penggemukan kambing, penggemukan lembu, dan modal turun sawah sama yaitu 1/3 untuk BUMG dan 2/3 untuk pengusaha. Sedangkan untuk gadai tanah yaitu 1/5 untuk BUMG dan 4/5 untuk pengusaha. Adapun maksud dari bagi hasil tersebut adalah bagi hasil dari keuntungan usaha yang dijalankan setelah dilakukan pengembalian modal awal yang dikembalikan kepada BUMG. Keuntungan tersebut diperoleh dari pengurangan hasil atau harga jual yang dikurangi dengan modal. Setelah diperoleh hasil dari keuntungan tersebut maka dilakukan bagi hasil berdasarkan hasil kesepakatan bagi hasil yang disajikan pada tabel 4 .

Sebelum dilakukan bagi hasil, tentunya hasil dari usaha tersebut harus dijual. Untuk penjualannya dilakukan dengan kerjasama oleh pengurus BUMG dan pihak yang menjalankan usaha. Untuk penjualan ternak biasanya dijual langsung ke pasar atau didatangi langsung oleh agen. Setelah dilakukan penjualan tersebut, maka pihak yang menjalankan usaha langsung memberikan atau mengembalikan modal kepada pengurus BUMG berdasarkan besarnya modal yang dikeluarkan BUMG untuk membeli bibit ternak yang diserahkan kepada pihak yang menjalankan usaha. Kemudian dihitung keuntungan yang diperoleh dari penjualan hasil usaha tersebut, lalu dihitunglah bagi hasil yang diterima masing-masing pihak yaitu antara pihak BUMG dan pihak yang menjalankan usaha sesuai

Analisis Pengelolaan Dana Desa dalam Pemberdayaan Ekonomi Masyarakat Melalui Badan Usaha Milik 602 Gampong di Gampong Capa Paloh Kecamatan Padang Tiji Kabupaten Pidie (Nurul Fitri, Anwar Deli, Fajri)

Jurnal Ilmiah Mahasiswa Pertanian Unsyiah, Vol. 3, No. 4, November 2018: 594-607 
dengan kesepatan bagi hasil dalam BUMG tersebut. Begitu pula dengan modal turun sawah, setelah panen maka dihitunglah keuntungan yang diperoleh dan dilakukan bagi hasil.

Selain adanya bagi hasil, juga terdapat kesepakatan mengenai sanksi. Sanksi merupakan hukuman atau ganjaran yang diberikan oleh BUMG kepada pihak yang menjalankan usaha apabila terjadinya beberapa hal yaitu seperti kematian ternak atau kehilangan ternak. Jika yang terjadi adalah ternaknya mati, maka kesepakatannya adalah kerugiannya tidak ditanggung oleh pihak yang menjalankan usaha melainkan BUMG yang menanggung kerugiannya. Sedangkan untuk ternak yang kehilangan atau ternak yang dicuri maka kerugiannya ditanggung oleh pihak yang menjalankan usaha sebesar 50\% (lima puluh persen) dari modal yang dikeluarkan untuk membeli bibit ternak tersebut.

\section{Bagi Hasil yang Diperoleh BUMG dan Pihak yang Menjalankan Usaha}

Bagi hasil diperoleh oleh dua pihak yang terlibat dalam menjalankan usaha, yaitu antara pihak BUMG dan pihak yang menerima modal. Berikut adalah bagi hasil yang diperoleh oleh BUMG, peternak, dan peminjam modal turun sawah.

Tabel 5. Bagi Hasil yang diperoleh BUMG dan pengusaha penggemukan kambing dan lembu

\begin{tabular}{|c|c|c|c|c|c|}
\hline \multirow{2}{*}{ No. } & \multirow{2}{*}{$\begin{array}{l}\text { Jenis Usaha } \\
\text { (Nama) }\end{array}$} & \multirow{2}{*}{$\begin{array}{c}\text { Harga Beli } \\
\text { (Jumlah) }\end{array}$} & \multirow{2}{*}{$\begin{array}{c}\text { Harga Jual } \\
\text { (Jumlah) }\end{array}$} & \multicolumn{2}{|c|}{ Bagi Hasil } \\
\hline & & & & BUMG & Peternak \\
\hline 1. & $\begin{array}{l}\text { Penggemukan } \\
\text { kambing } \\
\text { (DD) }\end{array}$ & $\begin{array}{c}\mathrm{Rp} \\
2.450 .000,-(2 \\
\text { ekor) }\end{array}$ & $\begin{array}{l}\text { Rp } 3.300 .000- \\
(2 \text { ekor })\end{array}$ & Rp 284.000,- & Rp 566.000,- \\
\hline 2. & $\begin{array}{l}\text { Penggemukan } \\
\text { kambing (SM) }\end{array}$ & $\begin{array}{l}\mathrm{Rp} \\
1.900 .000,-(2 \\
\text { ekor) }\end{array}$ & $\begin{array}{l}\text { Rp } 2.000 .000,- \\
(2 \text { ekor })\end{array}$ & Rp 34.000,- & Rp 66.000,- \\
\hline 3. & $\begin{array}{l}\text { Penggemukan } \\
\text { (SN) }\end{array}$ & $\begin{array}{l}\mathrm{Rp} \\
8.500 .000,-(1 \\
\text { ekor })\end{array}$ & $\begin{array}{l}\text { Rp } 9.000 .000,- \\
\quad(1 \text { ekor })\end{array}$ & Rp 150.000,- & Rp 350.000- \\
\hline 4. & $\begin{array}{l}\text { Penggemukan } \\
\text { (BL) }\end{array}$ & $\begin{array}{c}\mathrm{Rp} \\
8.150 .000,-(1 \\
\text { ekor) }\end{array}$ & $\begin{array}{c}\mathrm{Rp} \\
11.400 .000,-(1 \\
\text { ekor) }\end{array}$ & $\begin{array}{c}\mathrm{Rp} \\
1.250 .000,-\end{array}$ & $\begin{array}{c}\mathrm{Rp} \\
2.000 .000,-\end{array}$ \\
\hline 5. & $\begin{array}{l}\text { Penggemukan lembu } \\
\text { (SF) }\end{array}$ & $\begin{array}{c}\mathrm{Rp} \\
8.250 .000,-(1 \\
\text { ekor) }\end{array}$ & $\begin{array}{l}\mathrm{Rp} \\
10.700 .000,-(1 \\
\text { ekor) }\end{array}$ & Rp 818.000,- & $\begin{array}{c}\mathrm{Rp} \\
1.632 .000,-\end{array}$ \\
\hline
\end{tabular}

Sumber: Data primer diolah, 2018

Tabel 6. Bagi Hasil yang diperoleh BUMG dan peminjam modal turun sawah

\begin{tabular}{clcccc}
\hline \multirow{2}{*}{ No. } & \multicolumn{1}{c}{$\begin{array}{c}\text { Jenis Usaha } \\
\text { (Nama) }\end{array}$} & Pinjaman & Keuntungan & \multicolumn{2}{c}{ Bagi Hasil } \\
\cline { 5 - 6 } 1. & $\begin{array}{l}\text { Modal turun sawah } \\
\text { (FS) }\end{array}$ & $\mathrm{Rp}$ & $\mathrm{Rp}$ & $\mathrm{Rp}$ & $\mathrm{R}$ \\
& $13.000 .000,-$ & $9.000 .000-$ & $3.000 .000,-$ & $6.000 .000,-$ \\
\hline
\end{tabular}

Sumber: Data primer diolah, 2018

Dari tabel 5 dan 6 dapat dilihat masing-masing bagi hasil yang diterima oleh pihak BUMG, peternak, dan peminjam modal turun sawah. Bagi hasil tersebut baru diperoleh dari sebagian usaha yang telah menjual ternaknya dan juga keuntungan yang diperoleh dari modal turun sawah. Adapun usaha lainnya belum diperoleh bagi hasil disebabkan ternaknya yang belum dijual sehingga belum bisa diperoleh bagi hasilnya. Berdasarkan tabel di atas, adapun total keuntungan dari bagi hasil yang diperoleh BUMG adalah sebesar Rp

Analisis Pengelolaan Dana Desa dalam Pemberdayaan Ekonomi Masyarakat Melalui Badan Usaha Milik 603 Gampong di Gampong Capa Paloh Kecamatan Padang Tiji Kabupaten Pidie (Nurul Fitri, Anwar Deli, Fajri) Jurnal Ilmiah Mahasiswa Pertanian Unsyiah, Vol. 3, No. 4, November 2018: 594-607 
5.536.000,-. Tentu saja dengan bagi hasil yang diperoleh BUMG tersebut bisa menambah modal BUMG untuk kedepannya sehingga BUMG bisa menambah usaha yang akan dijalankan.

\section{Efektivitas dan Efesiensi Pengelolaan Dana Desa pada BUMG}

Jika dilihat dari segi keuangannya, alokasi Dana Desa untuk BUMG dari tahun 2016 mengalami peningkatan pada tahun 2017 yaitu sebesar 47,63\%. Yang mana pada tahun 2016 dana yang dialokasikan sebesar Rp 41.900.000,- sedangkan pada tahun 2017 yaitu sebesar Rp 80.000.000,-. Sedangkan untuk realisasinya, dengan menggunakan dana desa tahun anggaran 2016 BUMG ini berhasil menjalankan usaha dengan nilai yang dikeluarkan adalah sebesar Rp 63.900.000,- dan dengan dana desa tahun anggaran 2017 BUMG ini berhasil menjalankan usaha dengan nilai sebesar Rp 81.465.000,-. Jika dilihat dari realisasinya, bisa dilihat bahwa realisasi dana lebih besar dibandingkan dana yang tersedia. Hal itu disebabkan, pada BUMG ini dana yang telah diperoleh kembali dari hasil penjualan usaha tersebut kembali digunakan untuk modal yang lain. Berikut dapat dilihat mengenai efektivitas realisasi dana pada BUMG ini.

Tabel 7. Persentase efektivitas dan efesiensi realisasi dana desa pada BUMG Capa Paloh

\begin{tabular}{cccccc}
\hline No. & $\begin{array}{c}\text { Dana Tersedia } \\
(\mathbf{R p})\end{array}$ & $\begin{array}{c}\text { Realisasi } \\
(\mathbf{R p})\end{array}$ & $\begin{array}{c}\text { Penerimaan } \\
(\mathbf{R p})\end{array}$ & $\begin{array}{c}\text { Persentase } \\
\text { Efektivitas }\end{array}$ & $\begin{array}{c}\text { Persentase } \\
\text { Efesiensi }\end{array}$ \\
\hline 1. & 121.900 .000 & 145.365 .000 & 47.784 .000 & $119,2 \%$ & $304,21 \%$ \\
\hline
\end{tabular}

Sumber: Data primer diolah, 2018.

Jadi dapat dilihat pada tabel 7. persentase efektivitas dan efesiensi dari penggunaan dana desa pada BUMG Capa Paloh. Dari tabel tersebut dapat dilhat bahwa persentase yang diperoleh untuk efektivitas adalah sebesar 119,2\% yang diperoleh dari perbandingan realisasi dan dana yang tersedia dan dikali $100 \%$. Persentase efektivitas yang diperoleh 119,2\% menunjukkan bahwa pengelolaan dana pada BUMG Capa Paloh dilakukan secara sangat efektif dikarenakan nilai yang diperoleh lebih besar dari $100 \%$ yang menunjukkan kriteria sangat efektif. Hal tersebut dapat dilihat pada tabel 2 yang menjelaskan mengenai kategori dan persentase hasil analisis efektivitas.

Kemudian pada tabel 7. juga dapat dilihat bahwa nilai persentase efesiensi yang diperoleh adalah sebesar 304,21\% yang diperoleh dari perbandingan realisasi dan dana yang tersedia dan dikali $100 \%$. Nilai tersebut lebih besar dari $100 \%$ yang menunjukkan bahwa efesiensi dari penggunaan dana desa pada BUMG Capa Paloh tidak efesien sebagaimana yang telah disajikan pada tabel 1 mengenai kriteria persentase efesiensi. Hal itu disebabkan karena sampai waktu penelitian ini dilaksanakan, adapun penerimaan yang diterima oleh BUMG adalah sebesar nilai yang disajikan ditabel 5 dan 6. Hal tersebut dikarenakan ternak yang diusahakan belum dilakukan penjualan, hanya beberapa ternak saja yang baru dilakukan penjualannya, sehingga diperoleh nilai penerimaan sebesar itu. Dan juga, untuk gadai sawah tersebut belum dilakukannya panen sehingga belum bisa dihitung keuntungannya.

\section{Pengaruh BUMG terhadap Pemberdayaan Ekonomi Masyarakat}

Dari hasil wawancara terhadap masyarakat Gampong Capa Paloh yang menerima modal usaha dari BUMG, mereka mengatakan bahwa modal tersebut dirasakan bermanfaat dalam membantu menambah pendapatan. Hal itu dibuktikan pada tabel 5 dan tabel 6 yang mana pada tabel tersebut dapat dilihat bahwa mereka memperoleh keuntungan dari hasil penjualan dan bagi hasil yang dijalankan. Sampai waktu dilaksanakan penelitian ini, belum

Analisis Pengelolaan Dana Desa dalam Pemberdayaan Ekonomi Masyarakat Melalui Badan Usaha Milik 604 Gampong di Gampong Capa Paloh Kecamatan Padang Tiji Kabupaten Pidie (Nurul Fitri, Anwar Deli, Fajri)

Jurnal Ilmiah Mahasiswa Pertanian Unsyiah, Vol. 3, No. 4, November 2018: 594-607 
semua dari peternak dan petani sudah memperoleh keuntungan dari usaha yang dijalankan yang disebabkan karena belum dilakukan penjualan untuk ternak yang usahakan. Pemberian modal dari BUMG juga belum dirasakan oleh semua masyarakat dikarenakan masih minimnya dana. Meskipun pengaruhnya belum dirasakan oleh semua masyarakat Gampong Capa Paloh yang dikarenakan masih dirasakan minimnya dana yang dialokasikan untuk BUMG sehingga hanya sebagian masyarakat yang bisa menggunakan modal tersebut dan telah merasakan manfaatnya.

Masyarakat yang telah menerima modal dari BUMG memberikan respon yang positif terhadap jalannya BUMG dan mereka mengharapkan kedepannya agar penyertaan modal dari dana desa untuk BUMG bertambah. Dengan bertambahnya modal tersebut, BUMG bisa mengembangkan usaha dan bisa menambah usaha baru dan diharapkan akan menyerap tenaga kerja dari masyarakat Gampong Capa Paloh. Dengan begitu, maka akan terjadi peningkatan pemberdayaan ekonomi masyarakat dan juga bisa menambah pendapatan desa.

\section{Simpulan}

\section{SIMPULAN DAN SARAN}

Berdasarkan hasil penelitian dan pembahasan maka didapatkan beberapa kesimpulan sebagai berikut :

1. Pengelolaan BUMG Gampong Capa Paloh sebagian besarnya telah dilakukan sesuai dengan peraturan di dalam peraturan Menteri Desa, Pembangunan Daerah Tertinggal, dan Transmigrasi Republik Indonesia Nomor 4 Tahun 2015 tentang pendirian, pengurusan dan pengelolaan, dan pembubaran Badan Usaha Milik Desa. Hanya saja masih ada beberapa yang belum dijalankan sesuai peraturan tersebut seperti belum adanya $\mathrm{AD}$ dan ART mengenai pengelolaan BUMG, belum adanya pengawasan dari pendamping desa.

2. Diperoleh nilai persentase efektivitas yaitu $119,2 \%$ yang berarti bahwa sangat efektif. Sedangkan nilai persentase efesiensi diperoleh sebesar 304,21\% yang berarti bahwa penggunaan dananya tidak efesien yang dikarenakan hanya beberapa ternak yang baru dilakukan penjualannya.

\section{Saran}

Berdasarkan hasil penelitian, saran yang dapat diberikan adalah sebagai berikut :

1. Diperlukan pengurus BUMG beserta pemerintah gampong untuk membuat Qanun gampong tentang pembentukan Badan Usaha Milik Gampong (BUMG) yang memuat bentuk organisasi, kepengurusan, hak dan kewajiban, permodalan, bagi hasil usaha, keuntungan dan kepailitan, kerjasama dengan pihak ketiga, mekanisme pertanggungjawaban, pembinaan dan pengawasan masyarakat sebagaimana yang telah dijelaskan di dalam Peraturan Bupati Pidie Nomor 14 Tahun 2012.

2. Penelitian lanjutan diharapkan adanya penelitian tentang analisis perbandingan pengelolaan BUMG beberapa tempat atau gampong.

\section{DAFTAR PUSTAKA}

Andini, U.H., Mochamad, S.S., dan Ainul, H. Pemberdayaan Ekonomi Masyarakat dari Desa Tertinggal Menuju Desa Tidak Tertinggal (Studi di Desa Muktiharjo Kecamatan Margorejo Kabupaten Pati). Jurnal Administrasi Publik(JAP). Vol. 2. No. 12. 
Arsiyah. 2009. Pemberdayaan Masyarakat dalam Pembangunan Ekonomi Desa (Studi Kasus Pemberdayaan Masyarakat Industri Kecil Krupuk Ikan di Desa Kedungrejo, Kecamatan Jabon, Kabupaten Sidoarjo. Jurnal Wacana. Vol. 12. No. 2.

Athsil, M. 2017. Pengembangan Ekonomi Masyarakat Melalui Badan Usaha Milik Desa (BUMDes) di Desa Hanura Kecamatan Teluk Pandan Kabupaten Pesawaran. Skripsi. Jurusan Pengembangan Masyarakat Islam. Fakultas Dakwah dan Ilmu Komunikasi. Universitas Islam Negeri Raden Intan. Lampung.

Ayundar, R. 2015. Pemberdayaan Ekonomi Masyarakat Melalui Kelompok Bhakti Manunggal di Dusun Tulung Desa Srihardono Pundong Bantul Yogyakarta. Skripsi. Jurusan Ilmu Kesejahteraan Sosial. Fakultas Dakwah dan Komunikasi. Universitas Islam Negeri Sunan Kalijaga. Yogyakarta.

Bungin, B. 2007. Penelitian Kualitatif: Komunikasi, Ekonomi, Kebijakan Publik dan Ilmu Sosial Lainnya. Putra Grafika, Jakarta.

Eprizal. 2014. Pelaksanaan Pemberdayaan Ekonomi Masyarakat Kampar Melalui Lembaga Ekonomi Desa di Desa Batusasak Kecamatan Kampar Kiri Hulu Kabupaten Kampar Tahun 2010-2012. Jurnal Fisip. Vol. 1. No. 2.

Harahap, E.F. 2012. Pemberdayaan Masyarakat dalam Bidang Ekonomi untuk Mewujudkan Ekonomi Nasional yang Tangguh dan Mandiri. Jurnal Manajemen dan Kewirausahaan. Vol.3. No. 2.

Huda, N. 2015. Hukum Pemerintahan Desa. Malang: Setara Press.

Kartika, N.K.D.C., Ni, K.S., dan Made, A.W. 2017. Efektivitas Pengelolaan Dana pada Badan Usaha Milik Desa Kerta Danu Mandara di Desa Songan A. Jurnal S1 Ak Universitas Pendidikan Ganesha. Vol. 8. No. 2.

Kila, K.K. 2016. Pengelolaan Alokasi Dana Desa dalam Meningkatkan Pemberdayaan Masyarakat di Desa Miau Baru Kecamatan Kongbeng Kabupaten Kutai Timur. Jurnal Administrasi Negara. Vol. 5. No. 1. Hal. 5194.

Maryunani. 2008. Pembangunan BUMDes dan Pemberdayaan Pemerintah Desa. Bandung: CV Pustaka Setia.

Muntahanah dan Murdijaningsih dalam Yuliani. 2017. Pengaruh Kepemimpinan Kepala Desa Terhadap Pembiayaan Program Pembangunan yang Bersumber dari Alokasi Dana Desa (Desa Cibalung, Kecamatan Cijeruk, Kabupaten Bogor). Skripsi. Departemen Sains Komunikasi dan Pengembangan Masyarakat. Fakultas Ekologi Manusia. Institut Pertanian Bogor. Bogor.

Novita, D. 2016. Analisis Efisisensi dan Efektivitas Pengelolaan Anggaran Dana Desa Tahun 2015 di Kecamatan Leuwiliang Kabupaten Bogor Provinsi Jawa Barat. Skripsi. Jurusan Ilmu Ekonomi dan Studi Pembangunan. Fakultas Ekonomi dan Bisnis. Universitas Islam Negeri Syarif Hidayatullah. Jakarta.

Oleh, H.F. 2014. Pelaksanaan Kebijakan Alokasi Dana Desa (ADD) dalam Memberdayakan Masyarakat Desa di Desa Cerme, Kecamatan Grogol, Kabupaten Kediri. Jurnal Kebijakan dan Manajemen Publik. Vol. 2. No. 1. Hal. 5.

Peraturan Menteri Dalam Negeri Nomor 113 Tahun 2014 Tentang Pengelolaan Keuangan Desa.

Peraturan Menteri Desa, Pembangunan Daerah Tertinggal, dan Transmigrasi Republik Indonesia Nomor 4 Tahun 2015 Tentang Pendirian, Pengurusan dan Pengelolaan, dan Pembubaran Badan Usaha Milik Desa.

Analisis Pengelolaan Dana Desa dalam Pemberdayaan Ekonomi Masyarakat Melalui Badan Usaha Milik 606 Gampong di Gampong Capa Paloh Kecamatan Padang Tiji Kabupaten Pidie (Nurul Fitri, Anwar Deli, Fajri) Jurnal Ilmiah Mahasiswa Pertanian Unsyiah, Vol. 3, No. 4, November 2018: 594-607 
Peraturan Menteri Desa, Pembangunan Daerah Tertinggal, dan Transmigrasi Republik Indonesia Nomor 22 Tahun 2016 Tentang Penetapan Prioritas Penggunaan Dana Desa Tahun 2017.

Peraturan Menteri Keuangan Republik Indonesia Nomor 49/PMK.07/2016 Tentang Tata Cara Pengalokasian, Penyaluran, Penggunaan, Pemantauan dan Evaluasi Dana Desa.

Peraturan Pemerintah Republik Indonesia Nomor 60 Tahun 2014 Tentang Dana Desa yang Bersumber dari Anggaran Pendapatan dan Belanja Negara.

Putra, C.K., Ratih N.P., dan Suwondo. Pengelolaan Alokasi Dana Desa dalam Pemberdayaan Masyarakat Desa (Studi pada Desa Wonorejo Kecamatan Singosari Kabupaten Malang. Jurnal Administrasi Publik. Vol. 1. No. 6.

Rafisa, S. 2004. Perkembangan Pengusaha Kecil Sebelum dan Sesudah Menerima Dana Pemberdayaan Ekonomi Rakyat (PER) di Kota Banda Aceh. Skripsi. Jurusan Manajemen. Fakultas Ekonomi. Universitas Syiah Kuala. Banda Aceh.

Ramadana, C.B., Heru, R., dan Suwondo. Keberadaan Badan Usaha Milik Desa (BUMDes) sebagai Penguatan Ekonomi Desa (Studi di Desa Landungsari, Kecamatan Dau, Kabupaten Malang). Jurnal Administrasi Publik (JAP). Vol. 1. No. 6.

Ridlwan, Z. 2014. Urgensi Badan Usaha Milik Desa (BUMDES) dalam Pembangunan Perekonomian Desa. Jurnal Ilmu Hukum. Vol. 8. No. 3.

Rosalinda, O. 2014. Pengelolaan Alokasi Dana Desa (ADD) dalam Menunjang Pembangunan Pedesaan (Studi Kasus : Desa Segodorejo dan Desa Ploso Kerep, Kecamatan Sumobito, Kabupaten Jombang). Jurnal Ilmiah. Jurusan Ilmu Ekonomi. Fakultas Ekonomi dan Bisnis. Universitas Brawijaya. Malang.

Siregar, F.A. dan Fazli, S.B. 2017. Analisis Efektivitas dan Efisiensi Pengelolaan Keuangan Desa (Studi pada Desa di Kabupaten Deli Serdang). Jurnal Ilmiah Mahasiswa Ekonomi Akuntansi. Vol. 2. No. 4.

Sulistiyani, A.T. 2004. Kemitraan dan Model-Model Pemberdayaan. Gaya Media, Yogyakarta.

Sutrisno dalam Ulumiyah, I., A.J.A. Gani, dan L.I. Mindarti. Peran Pemerintah Desa dalam Memberdayakan Masyarakat Desa (Studi pada Desa Sumberpasir Kecamatan Pakis Kabupaten Malang). Jurnal Administrasi Publik. 1 : 892.

Udhiyani, N.M.V., dkk. 2014. Analisis Realisasi Kinerja Keuangan Dispenda Kabupaten Bandung Berdasarkan Value For Money Terhadap PHR Tahun 2008-2012. Jurnal Pendidikan Ekonomi. Vol. 4. No. 1.

Undang-Undang Republik Indonesia Nomor 6 Tahun 2014 Tentang Desa.

Analisis Pengelolaan Dana Desa dalam Pemberdayaan Ekonomi Masyarakat Melalui Badan Usaha Milik 607 Gampong di Gampong Capa Paloh Kecamatan Padang Tiji Kabupaten Pidie (Nurul Fitri, Anwar Deli, Fajri) Jurnal Ilmiah Mahasiswa Pertanian Unsyiah, Vol. 3, No. 4, November 2018: 594-607 